\title{
Erratum to: JCCS: a comprehensive journal for publishing all aspects of cell communication and signaling
}

\author{
Bernard Perbal
}

Published online: 1 February 2014

(C) The International CCN Society 2014

Erratum to: Journal of Cell Communication and Signaling DOI: 10.1007/s12079-013-0212-8

During the publication of this editorial the abstract was inadvertently mislabeled as summary, the abstract of this editorial should be:

The Journal of Cell Communication and Signaling (JCCS) is evolving and becoming even more comprehensive than it has been until now. JCCS should not be mistaken for CCS which I created in 2002, is separate from JCCS, and has been managed since 2008 by another group. I describe below the scientific reasons for the changes that made us decide to expand the topics of JCCS.

Initially created as the journal of the International $\mathrm{CCN}$ Society (ICCNS), it now addresses all aspects of Cell
Signaling and Cell Communication. It is the first journal offering such a wide scope in the Cell Signaling fields.

In addition to the JCCS matters, I also provide here a brief update on the 7th International Workshop on the CCN Family of Genes, which was held in Nice, October 2013.

This very successful meeting is rooted in the discovery of $\mathrm{CCN} 1, \mathrm{CCN} 2$ and $\mathrm{CCN} 3$ (initially designated Cyr61, CTGF, and Nov), later expanded with the inclusion of the WISP-1-3 proteins, now designated CCN4, CCN5 and CCN6. The field is evolving at a great pace, and the biological properties of the $\mathrm{CCN}$ proteins overlap with many essential signaling pathways controling key aspects of cell survival, behavior and death.

We welcome all readers to join the ICCNS and send their manuscripts to JCCS.

The online version of the original article can be found at http:// dx.doi.org/10.1007/s12079-013-0212-8.

B. Perbal $(\bowtie)$

International CCN Society, Paris, France

e-mail: bperbal@gmail.com 